\title{
平成25年台風18号を対象とした \\ WRFによる降水の再現と海面水温温暖化実験 \\ REPRODUCTION OF THE HEAVY RAINFALL BY TYPHOON 1318 \\ AND ITS SST GLOBAL WARMING NUMERICAL EXPERIMENT \\ USING A MESO-SCALE METEOROLOGICAL MODEL
}

\author{
能登谷拓 ${ }^{1}$ ・ 小林健一郎 2 - 奥勇一郎 3 ・ 木村圭佑 ${ }^{4}$ \\ Taku NOTOYA, Kenichiro KOBAYASHI, Yuichiro OKU and Keisuke KIMURA \\ 1学生会員 神戸大学 大学院工学研究科（†657-8501 神戸市灘区六甲台町1-1） \\ 2正会員 Dr.-Ing. 博（工） 神戸大学准教授 都市安全研究センター（†657-8501 神戸市灘区六甲台町1-1） \\ ${ }^{3}$ 非会員 博 (理) 大阪市立環境科学研究所 調查研究課（广543-0026 大阪市天王寺区東上町 8-34） \\ 4学生会員 神戸大学 大学院工学研究科（干657-8501 神戸市灘区六甲台町1-1）
}

\begin{abstract}
Recently heavy rains occur frequently and researchers consider a climate change may be one of the causes. Thus, this study estimates the influence of the sea surface temperature changes on rainfall intensity due to a Typhoon. First the Typhoon No.18, 2013 which caused heavy damage on Kyoto and Shiga prefectures due to the heavy rainfall is reproduced (control run). Then its SST global warming experiment is carried out using latest meso-scale meteorological model WRF. As the result of the SST global warming experiment, the catchment average rainfall of the Yodogawa river above Hirakata becomes 1.5 times larger than that of the control run. This result indicates a possibility that further heavier rainfall may occur in the future due to a climate change.
\end{abstract}

Key Words : WRF, SST global warming experiment, climate change, Yodogawa river catchment

\section{1. 研究の背景}

我が国は島国で国土が小さいうえに，山間部が 多い，そのため国内の多くの河川は，流域面積が小 さく急勾配となっている．大陸の広大な平地を流れ る河川に比して，上流地域で降った雨がすぐに下流 へと流れ込むため，短時間に大幅な水位上昇が起こ りやすく，河川の氾濫による短期的な洪水災害が発 生しやすくなっている. 加えて我が国は台風の常襲 地帯であり，洪水により古くから社会的，人的な被 害を受けてきた。2013年には台風18号が愛知県豊橋 市付近より日本列島に上陸し, 四国から北海道にか けての広い範囲に大雨をもたらした。近畿地方にお いては，通常太平洋側に比して降水量の少ない日本 海側の地域でも豪雨となり, 淀川水系の桂川や宇治 川が氾濫するなど, 京都府や滋賀県を中心として大 規模な浸水被害が生じた。

また，IPCC第4次報告書は，地球温暖化の影響に より今後台風が強大化していくことを指摘している 1)。そのため，上記のように洪水リスクの高い我が 国において治水計画を考えるうえでは，温暖化が台 風の降水特性に与える影響を定量的に把握すること が求められている.

昨今, 将来気候場の台風による影響評価を試みた
研究は数例なされている。例えば, 奥ら (2010) は, 気象庁気象研究所の超高解像度全球大気モデル MRI-AGCM-3.2 $\mathrm{S}^{2}$ により再現された 21 世紀末に日本 一来襲する台風を対象とした複数経路計算を行い, 最悪ルートにおける地上風速や降水量の可能最大值 の推定を行っている3). 他方, 吉野ら (2010) は戦 後最大の被害をもたらした伊勢湾台風をモデル台風 として, 複数の初期值, 境界值を用いた数值実験を 行い, 将来気候場における可能最大級台風がもたら 寸降水量を算出している4).

本研究は, メソ気象モデルを用いた温暖化実験に より, 淀川流域を対象とした将来的な大雨の影響評 価を行うものである。具体的には，近年淀川流域に 最も影響を与えた平成25年台風18号を対象とした降 水の再現と, 温暖化差分を加えた海面水温を境界值 とする海面水温温暖化実験を行う。本来温暖化の影 響を厳密に評価するためには, 気温, 水蒸気量, 気 圧などのあらゆる諸物理量の気候変動の影響を考慮 した擬似温暖化実験の手法が用いられるべきという 報告がある ${ }^{5)}$. しかしながら，一般に擬似温暖化実 験における温暖化差分の計算は，例えば本研究のよ うに9月の事例を対象とする場合，将来における9月 の気候值から現在における9月の気候值の差を温暖 化差分として求める。 あくまで平均的な気象場の変 
化を反映させただけであって，将来変化のゆらぎの 部分は考慮されない。温暖化予測実験において大気 の状態が極端に不安定な気象場が計算され，極端に 強い台風が計算されたとしても，前述の方法で温暖 化差分を計算すると，必ずしも台風の発達を促進す るような温暖化差分にならない可能性がある。例え ば，大気が一様に温暖化するのではなく，下層に比 べて中上層における温度上昇の方が大きければ大気 はより安定な状態になり, 対流の発達は抑制される ことになる、つまり, 台風の発達が抑制され, 結果 として降水量が減少する場合がある。一方, 海面水 温温暖化実験では大気側の温暖化を全く考慮してお らず，海面水温の上昇により大気の下層は少なから ず気温上昇することから, 台風の発達が好都合とな る大気の状態がより不安定化した場合の気象環境が 提供される。将来の大雨による影響評価が目的であ る本研究では，流域の総合的な治水計画策定の視点 から対象台風がより多くの雨をもたらす環境を設定 する必要があり，擬似温暖化実験による評価も重要 であるが今回は海面水温温暖化実験に着目した。

\section{2. 平成25年台風18号の概要}

日本時間9月 13 日3時（本稿では特に断りのない限 り，日時は日本時間とする）に小笠原諸島近海で発 生した台風18号は西寄りに進んだのち，勢力を上げ ながら北上し，16日の8時前に暴風域を伴って愛知 県豊橋市付近に上陸した.上陸した台風は関東甲信 地方，東北地方を通過し，三陸沖へと抜け，16日21 時に北海道の東で温帯低気圧となった。 中心気圧は 最低で960hPaを記録した。 日本海から流入した湿潤 な大気の影響により近畿地方, 東海地方を中心とし た広い範囲で16日未明から記録的な大雨となった。 特に京都府, 滋賀県, 福井県の3府県には16日5時5 分に大雨特別警報が発表された。「予想される現象 が特に異常であるため重大な災害の起こる恐れが著 しく大きい旨を警告して行う警報」と定義される特 別警報が, 同年8月30日の運用開始後, 初めて適用 された. 代表観測地点の9月15日から16日までの総 降水量は, 京都府京都で $250.5 \mathrm{~mm}$, 京都府園部で $311.5 \mathrm{~mm}$, 滋賀県大津で $328.0 \mathrm{~mm}$, 滋賀県信楽で 332.0mmとなった6). 京都府では由良川や桂川が汇 濫し, 渡月橋がほぼ冠水するなど各地で住宅の浸水, 道路の損壊が相次いだ。府内において, 損壊や浸水 による住家被害は合計で5400棟に上った。滋賀県に おいても，河川の決壊などが起こり，全域において 浸水被害が広がった .

台風18号が発達しながら接近，上陸した原因とし て, 台風上陸前の日本列島付近での海面水温が平年 よりも $1 \sim 2{ }^{\circ} \mathrm{C}$ 程度高かったことが挙げられる（図-1, 図-4）. 秋の台風は北上するにつれて海面水温の低 下により, 日本列島付近では衰弱することが多いが， 本事例では海面水温が $27^{\circ} \mathrm{C}$ 以上の台風が発達しやす い条件となっていた。図-1に9月14日9時における海

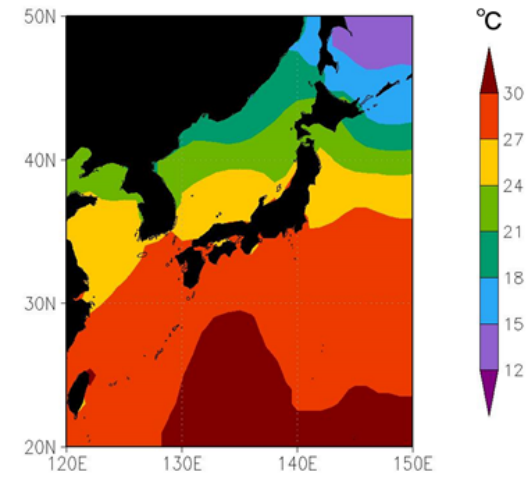

図-1９月14日9時における海面水温分布 (NCEP全球客観解析データFNLをもとに作成)

面水温分布を示す. 海面水温 $27^{\circ} \mathrm{C}$ 以上の水域が北陸 地方まで達しており，日本周辺で平年よりも海面水 温が高くなっていたことがわかる.

\section{3. 数値実験概要}

\section{（1）使用モデル}

今回の実験では最新のメソ気象モデルである The Weather Research and Forecasting (WRF) Model を用い た. WRF は, 大気の研究および実用的な気象予報 の用途で用いられるために開発された，3 次元完全 圧縮性非静力学モデルである。開発は 1990 年代の 後半から始まり， National Center for Atmospheric Research (NCAR), National Center for Environmental Prediction (NCEP), Forecast Systems Laboratory (FSL), Air Force Weather Agency (AFWA), University of Oklahoma（オクラホマ大学）らによって共同で行 われた. NCAR と The Pennsylvania State University (ペンシルバニア州立大学) によって共同開発され た非静力学モデルである MM5 の次世代モデルとし て位置づけられている。高精度な計算スキームや最 新の物理モデルが導入されており，突発的な豪雨の 予測, 再現に適したモデルである ${ }^{8)}$. 研究用の Advanced Research WRF (ARW) と実業用の Nonhydrostatic Mesoscale Model (NMM) の二種の解 法が用意されている. なお，今回用いたのは ARW である。

\section{(2) 再現実験}

淀川流域における降水が観測值と近くなることを 目標として，平成 25 年台風 18 号の再現実験を行う. 初期值, 境界值を NCEP の Final Operational Model Global Analysis data (全球客観解析データ FNL) で 与えた。 なお, NCEP/FNL の空間解像度は 1 ○であ り，時間間隔は 6 時間である。表-1 に実験の計算 条件, 図-2 に計算領域を示す。計算領域は水平解 像度 $20 \mathrm{~km}$ の日本全域を含む親領域 (D1) と twoway nesting 手法による近畿地方周辺の子領域 (D2) を設定した ${ }^{9)}$. D2 では降水の水平解像度依存性を 調べるために，3つの異なる水平解像度 $(5 \mathrm{~km}, 4 \mathrm{~km}$, 
表-1＼cjkstart計算条件

\begin{tabular}{|c|c|c|}
\hline 気象モデル & \multicolumn{2}{|c|}{ WRF/ARW 3.5.1 } \\
\hline \multirow[t]{4}{*}{ 格子点数 } & D1 & $150 \times 150 \times 30$ \\
\hline & $\mathrm{D} 2-5 \mathrm{~km}$ & $73 \times 73 \times 30$ \\
\hline & $\mathrm{D} 2-4 \mathrm{~km}$ & $91 \times 91 \times 30$ \\
\hline & $\mathrm{D} 2-2 \mathrm{~km}$ & $181 \times 181 \times 30$ \\
\hline 水平解像度 & \multicolumn{2}{|c|}{$20 \mathrm{~km}, 5 \mathrm{~km}, 4 \mathrm{~km}, 2 \mathrm{~km}$} \\
\hline 時間ステップ & \multicolumn{2}{|c|}{$100 \mathrm{~s}, 25 \mathrm{~s}, 20 \mathrm{~s}, 10 \mathrm{~s}$} \\
\hline 計算開始日時 & \multicolumn{2}{|c|}{ 2013/09/12 09JST } \\
\hline 計算終了日時 & \multicolumn{2}{|c|}{ 2013/09/16 21JST } \\
\hline 境界層スキーム & \multicolumn{2}{|c|}{ Mellor-Yamada-Janjic } \\
\hline 雲微物理スキーム & \multicolumn{2}{|c|}{$\begin{array}{c}\text { WRF Single-Moment } \\
\text { 6-class scheme }\end{array}$} \\
\hline \multirow[t]{4}{*}{ 積雲スキーム } & D1 & Kain-Fritsch \\
\hline & $\mathrm{D} 2-5 \mathrm{~km}$ & Kain-Fritsch \\
\hline & $\mathrm{D} 2-4 \mathrm{~km}$ & None \\
\hline & $\mathrm{D} 2-2 \mathrm{~km}$ & None \\
\hline 接地層スキーム & \multicolumn{2}{|c|}{ Monin-Obukhov } \\
\hline
\end{tabular}

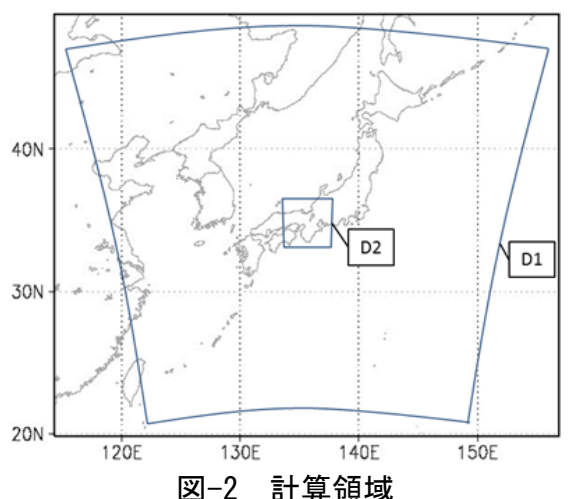

$2 \mathrm{~km})$ での計算を行った。今回はデータの同化は 行っていない.

\section{（3）海面水温温暖化実験}

海面水温温暖化実験では，再現実験で境界值とし て用いた海面水温（図-1）に温暖化差分を上乗せし た值を海面水温の境界值として用いた。将来

(2075-2099 年) における 9 月の月平均海面水温と 現在（1979-2003 年）のそれとの差を IPCC 第 4 次 報告書の SRES-A1B シナリオに基づく CMIP3 マル チモデルアンサンブル平均值で求め, これを海面水 温の温暖化差分とした ${ }^{10)}$ 。再現実験からの変更点 は海面水温のみであり, 再現実験と同様の条件でネ スティングを行った。図-3に 9 月の海面水温温暖 化差分を可視化した図を示す。日本付近の海域にお いて海面水温が大幅に上昇しており，特に北緯 40 度周辺では 2.5 度以上も高くなっている。実験で用 いた海面水温の境界值と過去の 9 月平均海面水温と の比較を図-4 に示す。過去の海面水温はハドレー センターのデータ ${ }^{11)}$ 用いており，各年の 9 月月 平均海面水温を台風 18 号が発達する期間に通過し た海域である東経 130-145 度, 北緯 20-35 度で領域 平均した值を示している（図-5の領域 1 参照)。ま た，図中の再現実験と海面水温温暖化実験について

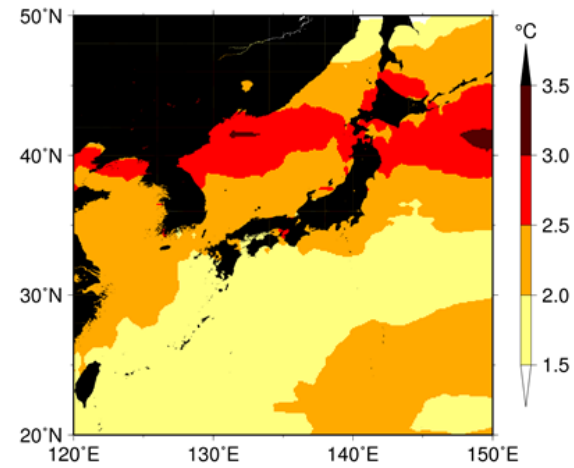

図-3 9 月の海面水温温暖化差分分布

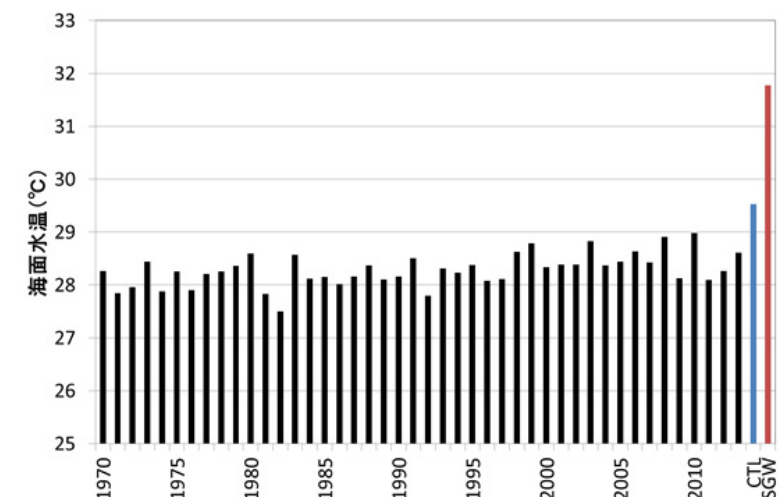

図-4 過去の9月平均海面水温と実験で用いた海面水温 の比較 (図中のCTLは再現実験, SGWは海面水温 温暖化実験を表す．）

は，それぞれの実験で用いた海面水温の境界值の平 均をとり，東経130-145度，北緯20-35度で領域平均 した值を示している。図-4から計算期間中の海面水 温は過去44年間の月平均值と比べると最も高い状態 であり，海面水温温暖化実験では，さらにそれを2 度ほど上回る状態であったことがわかる。

\section{4. 実験結果}

\section{（1）台風経路と中心気圧の比較}

図-5に各実験の台風経路と気象庁発表経路の比較 を示す. 各実験の台風は上陸後実際よりも北側の進 路となっているが，近畿地方周辺での位置は近く, 淀川流域で降水を比較するうえでは問題にならない 程度であると判断した。

図-6に図-5で示した各台風の中心気圧を示した。 再現実験では，台風の経路を比較的良く再現するこ とができたが，中心気圧を比較すると観測值よりも 全体的に低く，最低值は観測值よりも $30 \mathrm{hPa}$ 程度低 い結果となった。海面水温温暖化実験においても， 中心気圧が全体的に低くなっており，最低值は再現 実験よりもさらに40hPa低くなった。しかし，本研 究の解析対象はあくまで台風による雨であるため, 台風の構造自体の再現は目指しておらず，許容範囲 内であると判断した。

また，図-5 の台風経路において再現実験と海面 水温温暖化実験との間に若干の差がみられるのは, 気圧場の違いによるものである。海面水温の上昇は 
対流の発達に影響を与えるため, 再現実験と海面水 温温暖化実験では必ずしも同じ場所で対流（積乱雲） が発達するとはいえない，対流が発達する場所や強 さが変われば，それは気圧場に影響を与える. 結果 として再現実験と海面水温温暖化実験の気圧場が まったく同じになるとはいえない. 一方, 台風の位 置は気圧が最低となる場所で与え, 台風の経路は台 風の位置を経時的に追跡した結果である. そのため 再現実験と海面水温温暖化実験の台風経路に差が生 じている.

\section{（2）積算降水量の比較}

再現実験および海面水温温暖化実験により得られ た降水分布を，計算開始から終了までの積算值とし て示す. D1 における結果を気象庁の解析雨量と合

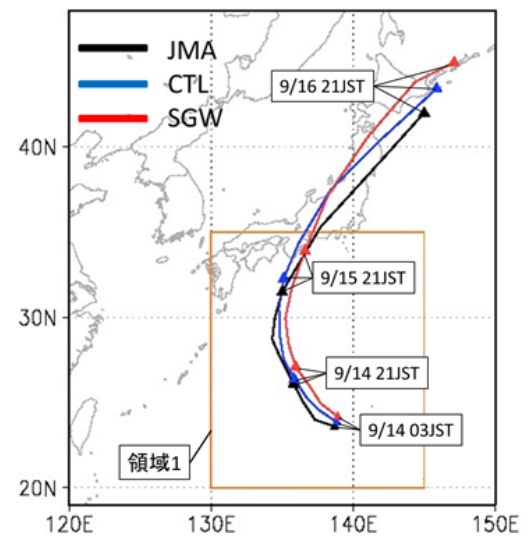

図-5 D1における台風経路の比較（JMAは気象庁発表経 路，CTLは再現実験，SGWは海面水温温暖化実験を 示している.)
わせて図-7 に示す. 再現実験に比べ海面水温温暖 化実験においては，降水域が大幅に広がっており， およそ北緯 25 度から 30 度にかけて積算降水量が $400 \mathrm{~mm}$ を超える領域が現れていることが見て取れ る. 一般に, 海面水温が上昇すると海面から大気へ の潜熱フラックスが増加する. 潜熱フラックスが増 加すると, 大気中に含まれる水蒸気量が増加する.

図-9 に両実験の 9 月 15 日 21 時における可降水量 （水蒸気量の鉛直積分）の比較を示した ${ }^{12)}$. 日本 付近における可降水量の差が顕著に表れていること がわかる，さらに，水蒸気量が増えると水蒸気凝結 による潜熱放出により大気がより暖められ，台風の ウォームコア（暖気核）がより発達する。その結果 として，海面水温が上昇する前に比べて，ある特定 の地域の降水量が増えるわけではなく全体として降

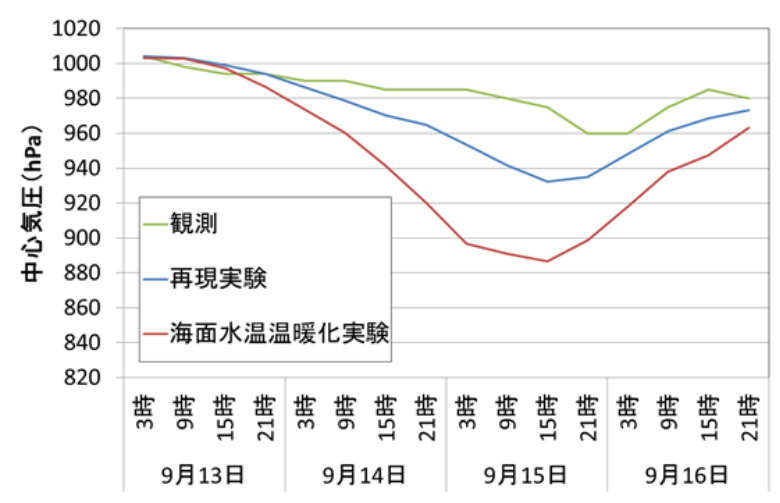

図-6 D1における台風中心気圧の比較
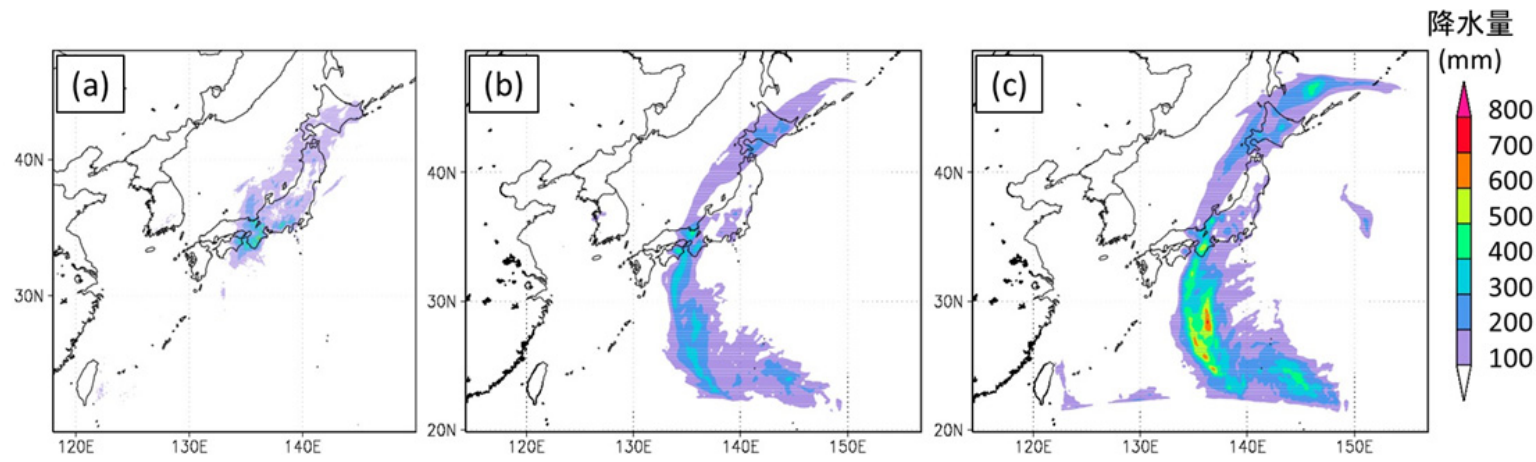

図-7 D1における積算降水量の比較

（（a）が解析雨量,

(b) が再現実験,

(c) が海面水温温暖化実験を示している. )

降水量
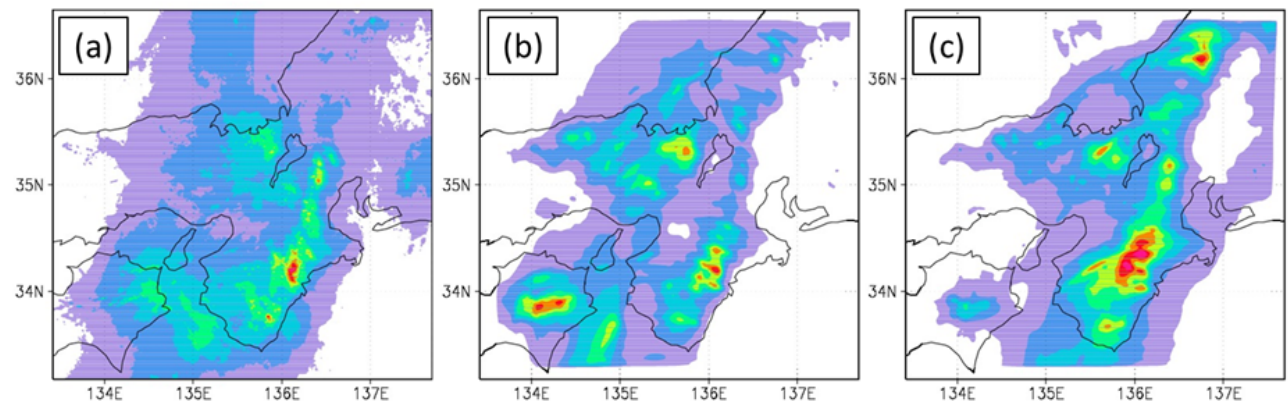

$(\mathrm{mm})$

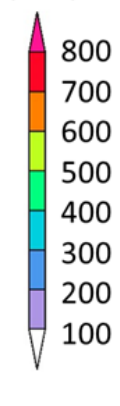

図-8Ｄ2-2kmにおける積算降水量の比較

（（a）が解析雨量，（b) が再現実験

(c)が海面水温温暖化実験を示している. ) 

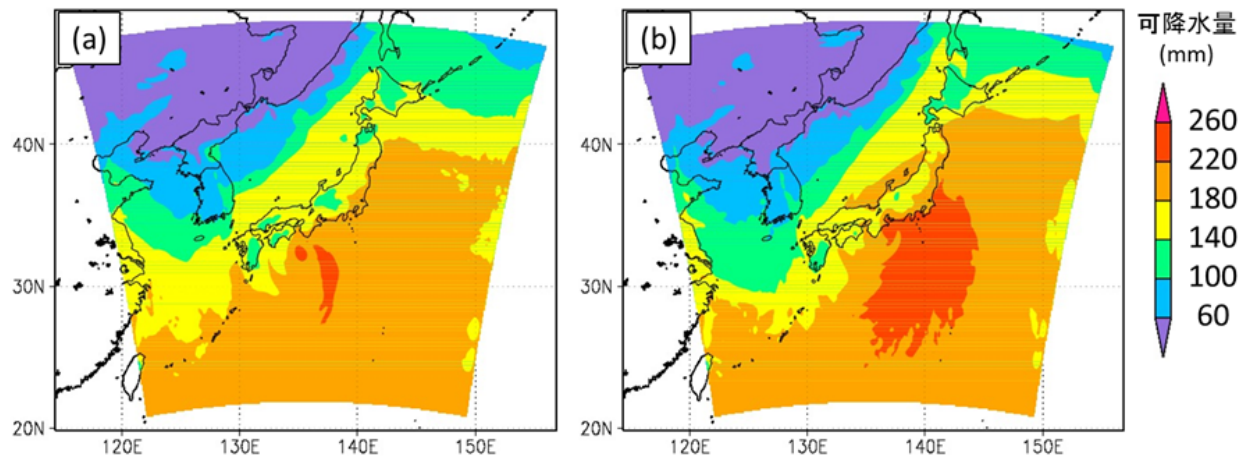

図-9 台風接近時（2013年9月15日21時）の可降水量の比較（(a)が再現実験, (b) が海面水温温暖化実験を 示している. )
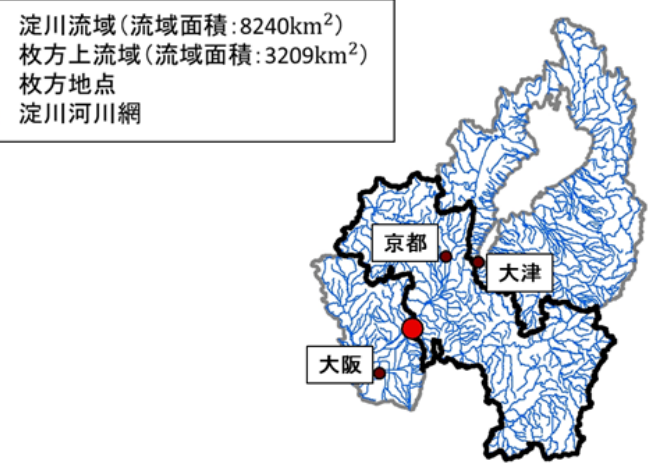

図-10 枚方上流域

水量が増える傾向がある。また同様に，D2-2km に おける結果を図-8 に示す。近畿地方周辺では, 再 現実験の台風の方が海面水温温暖化実験の台風より も北側の進路となっているため，降水量の多い範囲 が海面水温温暖化実験に比べ北に位置している。再 現実験に比べ海面水温温暖化実験では，紀伊半島中 央部から南部にかけての広い範囲で降水が多くなっ ていることが見て取れる。

\section{（3）枚方上流域における比較}

図-10に黒枠で示した枚方上流域における流域平 均降水量の比較を行った。流域平均降水量の観測值 は国土交通省の地上観測雨量により算出されたもの である。枚方地点は淀川流域における洪水防御の基 準地点であり，枚方上流域での降水の評価は流域の 治水計画策定の基準となる ${ }^{13)}$. 降水の評価のために, 枚方上流域での比較が最適であるとは限らないが, 今回は河川計画との整合性のために枚方上流域を評 価対象とした。なお，図中の大きい赤点で示した位 置が枚方地点である。図-11に枚方上流域における 流域平均1時間降水量の比較，図-12に流域平均積算 降水量の比較を示す。9月14日24時から16日21時ま での比較である。図-11，図-12の再現実験值および 海面水温温暖化実験值はD2-2kmの結果を示してい る。最大 1 時間降水量は，観測值が $23.0 \mathrm{~mm}$ （9月 15 日23時），再現実験が $25.9 \mathrm{~mm}$ （9月 16日 1時），海 面水温温暖化実験が $67.6 \mathrm{~mm}$ （9月 15 日21時）となっ ている。海面水温温暖化実験が，観測值のおよそ 2.9倍，再現実験のおよそ2.6倍である。図-5に示す ように再現実験と比較すると海面水温温暖化実験に

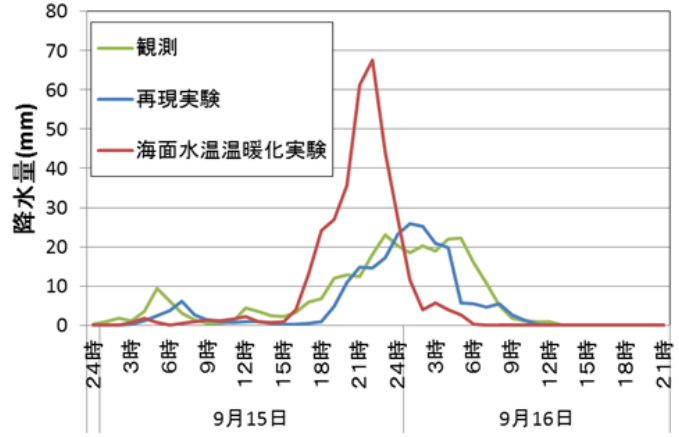

図-11 枚方上流域における流域平均1時間降水量

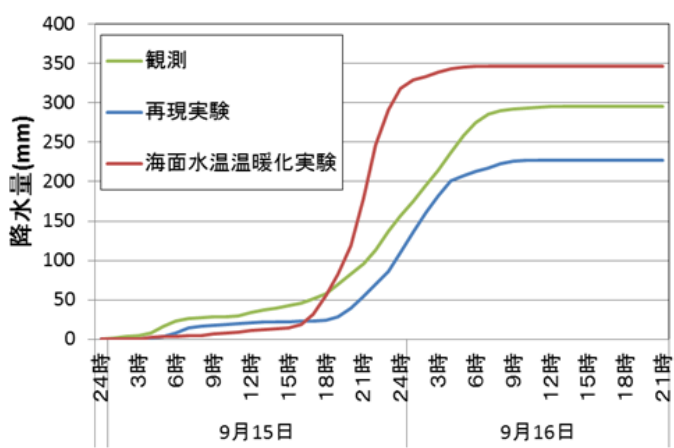

図-12 枚方上流域における流域平均積算降水量 口観測 』再現実験 曰海面水温温暖化実験

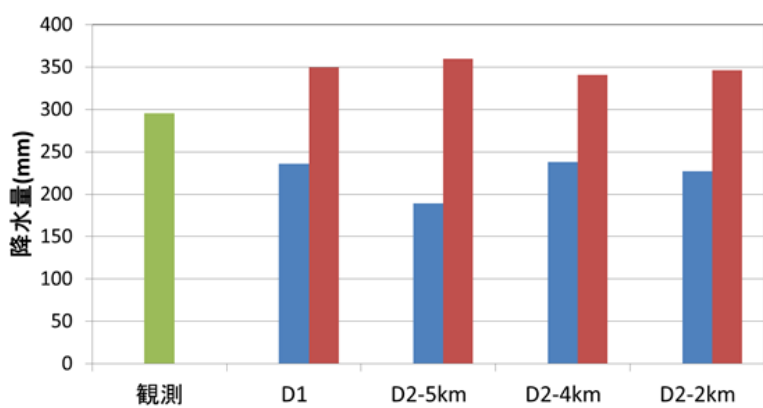

図-13 水平解像度の違いによる 枚方上流域積算降水量の差

おける台風の移動速度の方が大きくなっているため, 海面水温温暖化実験の降水は短時間に集中するとい う結果が表れている。流域平均積算降水量について は，最終的に観測值が $295.1 \mathrm{~mm}$ ，再現実験が $227.2 \mathrm{~mm}$ ，海面水温温暖化実験が $346.4 \mathrm{~mm}$ となって いる. 海面水温温暖化実験が観測值のおよそ 1.2 倍, 再現実験のおよそ1.5倍である。さらに，水平解像 度による再現性の違いを検証するために，図-13に 
各水平解像度での枚方上流域積算降水量を示す. 水 平解像度により観測值と再現実験值の差にばらつき が見られるが, 地形による詳細な降水の差が表れた ことや積雲スキームの有無が関係していると考えら れる. 海面水温温暖化実験については, 解像度を変 更しても大きな差は表れなかった．そのため海面水 温の上昇は，水平解像度の差に関わらず明確な降水 の増大をもたらしていることがわかる.

また，図-12および図-13の観測值と再現実験值と の比較から, 再現実験值は観測值よりも過小評価と なっていることがわかる。このような差は図-11に 示すように，強い降水の継続時間が観測よりも再現 実験において短くなっていることに起因している. 今後, シミュレーション結果を客観解析值に近づけ るなどの補正法の適用を検討する必要があるかもし れないが，海面水温温暖化実験結果の降水量は十分 に大きく，そのまま計画降雨の一つとすることも可 能ではないかと考える。なお，時間雨量が最大とな るタイミングやその值は再現実験と観測值で似通っ ており，台風18号による降水の特徴は良くとらえら れていると考える。

\section{5. 結語}

本研究では, 海面水温温暖化手法を用い, 淀川流 域を対象とした将来の気候変動影響下における台風 がもたらす降水の影響評価を行った。対象台風を, 淀川流域を含む近畿地方北部を中心に未曾有の豪雨 をもたらした平成25年台風18号とし, 将来の温暖化 した環境におけるこの台風がもたらす豪雨について の検討を行った. 実験の結果, 枚方上流域積算降水 量については, 海面水温温暖化実験が再現実験のお よそ1.5倍となっており，大幅な上昇が確認された。 なお，今回の実験では海面水温の将来変化のみを与 え, 大気場の将来変化については考慮していないた め, 降水が過大評価となっているものと考えられる. この点に関しては，擬似温暖化実験との違いとして 十分に留意する必要がある. しかしながら, 本研究 の目的は流域の治水計画策定に資するような結果を 得ることであり, 対象台風がより多くの雨をもたら す場合を想定したものである。一方, 現在の治水計 画は既往の降雨データに基づいて設定されたもので あり，これまで日本の安全を守ってきた。今後は将 来を見据えた研究結果が蓄積され, 気候変動の影響 も加味したより安全度の高い計画手法の確立がなさ れるべきであると考える.今回は降水のみの比較と なっているが，そのような計画策定に資するために， 地上での浸水域や河川流量の比較を行い, 㛜密に流 域に及ぼす影響を定量化することを想定している ${ }^{14)}$. また，台風による降水は地形による影響を大きく受 けるものである. そのため今回の手法を複数の事例 に適用したり, 経路の違いを考慮したりすることに よって，多数のシナリオからの影響を評価すること が必要であると考える.
謝辞: 第 2 著者は土木学会水工学委員会京都 - 滋賀 水害調査団（京都大学中川一団長, 竹林洋史幹事長) の一員として，国土交通省近畿地方整備局より水文 データを提供していただきました。本研究は気候変 動リスク情報創生プログラムの成果でもあります. ここに記して感謝いたします.

\section{参考文献}

1) Emanuel, K. A.: Increasing destructiveness of tropical cyclones over the past 30 years, Nature, Vol. 436, pp. 686688, 2005.

2) Mizuta, R., Yoshimura, H., Murakami, M., Matsueda, H., Endo, T., Ose, K., Kamiguchi, M., Hosaka, M., Sugi, S., Yukimoto, S., Kusunoki, A. and Kitoh, A.: Climate Simulations Using MRI-AGCM3.2 with 20-km Grid, Journal of the Meteorological Society of Japan. Ser. II, Vol. 90A, pp. 233-258, 2012.

3) 奥勇一郎, 吉野純, 石川裕彦, 竹見哲也, 中北英一: 将来の極端台風の複数経路計算による可能最大被害予 測, 京都大学防災研究所年報, 第53号B, pp. 371-375, 2010.

4) 吉野純，飯田潤士，安田孝志 : 紀伊半島に上陸する可 能最大級台風に伴う降水量の地球温暖化による変化, 土木学会水工学論文集, 第54巻, pp. 229-234, 2010.

5) 小林健一郎, 奥勇一郎, 寶馨, 石川裕彦, 竹見哲也, 中北英一：物理ダウンスケール法による極端台風を用 いた淀川流域の洪水評価, 京都大学防災研究所年報, 第55号B, pp. 9-14, 2012.

6) 気象庁 : 台風18号による大雨, 23 pp., 2013.

7) 土木学会水工学委員会 : 京都・滋賀水害調査速報会報 告書, 28 pp., 2013.

8) 辰巳賢一・竹見哲也・石川裕彦：WRFモデルを用いた 高解像度気象シミュレーションシステムの構築 : 豪雨 の事例解析, 京都大学防災研究所年報, 第 51 号 $\mathrm{B}, \mathrm{pp}$. 437-448, 2008.

9) Harris, L. M. and Durran, D. R.: An Idealized Comparison of One-Way and Two-Way Grid Nesting, Monthly Weather Review, Vol. 138, pp. 2174-2187, 2010.

10) Ishikawa, H., Oku, Y., Kim, S., Takemi, T. and Yoshino, J.: Estimation of a possible maximum flood event in the Tone River basin, Japan caused by a tropical cyclone, Hydrological Process, Vol. 27, pp. 3292-3300, 2013.

11) Rayner, N. A., Parker, D. E., Horton, E. B., Folland, C. K., Alexander, L. V., Rowell, D. P., Kent, E. C. and Kaplan, A.: Global analyses of sea surface temperature, sea ice, and night marine air temperature since the late nineteenth century, Journal of Geophysical Research (Atmospheres), Vol. 108, No. D14, 4407, 37 pp., 2003.

12) Pozo, D., Illanes, L., Caneo, M. and Curé, M.: PWV FORECAST VALIDATION AT ALMA SITE, Revista Mexicana de Astronomía y Astrofísica, Vol. 41, pp. 55-58, 2011.

13）立川康人, 佐山敬洋, 寶馨, 松浦秀起, 山崎友也, 山路昭彦, 道広有理 : 広域分布型物理水文モデルを用 いた実時間流出予測システムの開発と淀川流域一の適 用，自然災害科学，Vol. 26, No. 2, pp. 189-201, 2007.

14) 小林健一郎, 奥勇一郎, 中北英一, 中野満寿男, 寶 馨 : 伊勢湾台風擬似温暖化実験による淀川流域におけ る洪水規模の変化予測, 土木学会水工学論文集, 第58 巻, pp. 391-396, 2014.

(2014. 9. 30受付) 